\title{
Observations on the Marking Behaviour of a Coastal Population of Otters
}

\author{
S. M. MACDONALD \& C. F. MASON
}

\begin{abstract}
Macdonald S. M. \& Mason C. F., 1980: Observations on the marking behaviour of a coastal population of otters. Acta theriol., 25, 19: 245-253 [With 3 Figs.].

The marking behaviour of otters was studied around a sea loch in northwest Scotland, $32 \mathrm{~km}$ of shoreline being examined. Twelve used holts were found. They were situated in rocky outcrops and the average interholt distance was $1,100 \mathrm{~m}$ (range $450-2,000 \mathrm{~m}$ ). Holt entrances were heavily marked with spraints. Large accumulations of spraints ( $*$ lavatories $\ll$ ) tended to occur between holts and may have served as signals for otters travelling along the shore. Sixty-two per cent of 168 sprainting sites were within $150 \mathrm{~m}$ of holts. Otters in this area appear able to tolerate a certain level of disturbance from human activities. The marking behaviour of otters is discussed in relation to resources.

[Dept. Zool. \& Com. Physiol. Univ. Birmingham, Birmingham, U. K. (SIMM) and Dept. Biol., Univ. Essex, Colchester, U. K. (CFM).
\end{abstract}

\section{INTRODUCTION}

The otter Lutra lutra ( $\mathrm{L}$ in $\mathrm{n}$ a e us, 1758), although rare throughout much of England and Wales, is considered to be still fairly plentiful in parts of Scotland (Nature Conservancy Council, 1977). Many reasons have been advanced for the scarcity of the otter over much of Western Europe and recent work on a river catchment in England ( $\mathrm{M} \mathrm{a} \mathrm{c} \mathrm{d} \mathrm{o} \mathrm{n}$ a l d et al., 1978) suggested that the otter was dimited at present by a dearth of holts (dens) rather than by factors such as food supply or disturbance. This lack was related to riparian management and in particular to the removal of certain species of trees whose root systems provided holts. It seemed unlikely that trees would be important to otters on the coast of Western Scotland, but other features of habitat might affect their distribution.

Kru uk \& Hewson (1978) studied a population of otters on an uninhabited peninsula with a rocky shoreline in north west Scotland and a rocky, coastal habitat in Shetland was examined by W a ts o $\mathrm{n}$ (1978). By contrast, the present work was carried out on a sea loch where the shore consisted of both rock outcrops and extensive shingle 
beaches backed by low-lying pasture. Parts of the area were open to potential disturbance from farming, fishing and tourism.

The pattern of territorial marking by coastal otters described by Kruuk \& Hewson (1978) was different from that of riverine otters as described by Erlinge (1968). We attempted, by noting both the distribution and the intensity of marking, to investigate further the apparent differences in the behayiour of one species utilizing two differing habitats.

\section{SITE AND METHODS}

Loch Broom is a mainland North Minch sea loch $14.5 \mathrm{~km}$ in length lying in a mountainous area of Easter Ross, north west Scotland (see Fig. 1). The seaward part of the loch is of an estuarine type but a sill lies half way up the loch and the upper $7 \mathrm{~km}$ is fiordic type ( $\mathrm{Milne}$, 1972). The entrance to the loch has thus high salinity while in the upper basin there are lower salinities as freshwater enters from the River Broom. The loch is tidal throughout and the maximum depth is $70 \mathrm{~m}$. The shoreline comprises shingle beaches and rock outcrops with cliffs which, at high tide, leave no shore. At low tide dense belts of Fucus spp. are exposed. Areas of shingle are more extensive in the upper basin. The head of the loch and the mouth of the River Broom have considerable areas of tidal grassland.

About $5 \mathrm{~km}$ from the entrance to Loch Broom lies the town of Ullapool (pop. $c a 1,000$ ), a fishing community with a tourist industry. Along much of the valley are scattered houses and farms and many of these are close to the shore. Preliminary observations were made in September 1978 when the loch was disturbed both by tourists and by an influx of eastern European factory ships processing mackerel supplied from a fleet of fishing vessels from the Scottish east coast. During the period of our survey (29 December $1978-4$ January 1979 inclusive) both these disturbance factors were absent and only a few local fishing vessels remained.

During the survey $32 \mathrm{~km}$ of the shoreline were walked. The sheer cliffs at the extreme seaward end of the southern shore of the loch were inaccessible. All holts, sprainting sites and the amount of spraint (droppings) at each site were mapped. Some 90 man hours were spent in the field.

During the study period the air temperature never rose above freezing, the cliffs were covered with ice and there was a light snow cover making it possible to record and measure tracks of otters.

\section{RESULTS}

\section{1. Holts}

Twelve freshly marked holts were located. They were marked at their entrances with large deposits of spraint, the number of individual spraints being impossible to determine. Holts were found only in those areas of the shore with rock outcrops. Holts were found among bare rocks, where rock was overgrown with grass and bracken (Pteridium 
aquilinum) and where the roots of rowans (Sorbus aucuparia) were bound into the rock. Holts either had single entrances or resembled badger setts with several entrances. Both types of holt were being used at the time of the survey but evidence of culbs (footprints in

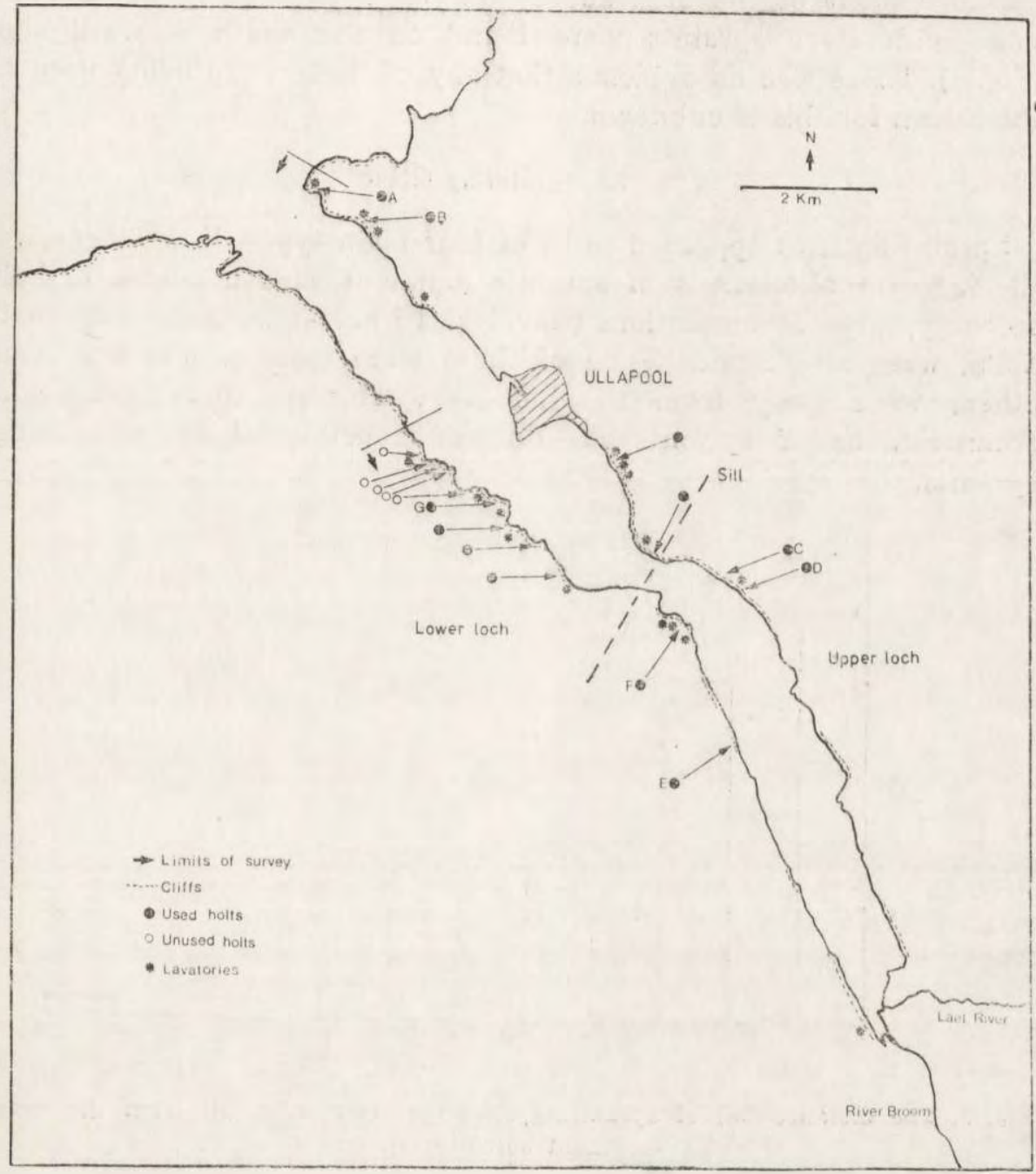

Fig. 1. Loch Broom showing the position of used holts, unused holts, and mlavatories s of otters. Letters against holts refer to those in Fig. 3.

snow) was only found at the latter type. One holt, occupied at the time, had its single entrance only $1 \mathrm{~m}$ above the high tide mark but most were considerably higher than this, up to $100 \mathrm{~m}$ above M.H.W.S.

The distribution of freshly marked holts is shown in Fig. 1 and it 
can be seen that they are not regularly spaced along the shore. The average interholt distance was $1,100 \mathrm{~m}(940 \mathrm{~m}$ mean straight-line distance) with a range of $450-2,000 \mathrm{~m}(260-1,840 \mathrm{~m}$, straight-line idistance). Only 4 of the 12 holts were found in the upper basin of the loch (55\% of the area surveyed). Six holts, lightly marked, and none with fresh spraints were found on the south seaward shore (Fig. 1). There was no evidence that any of these were being used but the reason for this is unknown.

\subsection{Sprainting Sites}

Sprainting sites appeared to be of four main types. First, there were the large accumulations of spraints found at the entrances to holts; secondly, large accumulations ("lavatories") not at the entrances to the holts, were also found. Some of these were close to the holt while others were away from the holt site. Thirdly, there were small accumulations of spraints $(2-10)$ and fourthly there were single spraints.

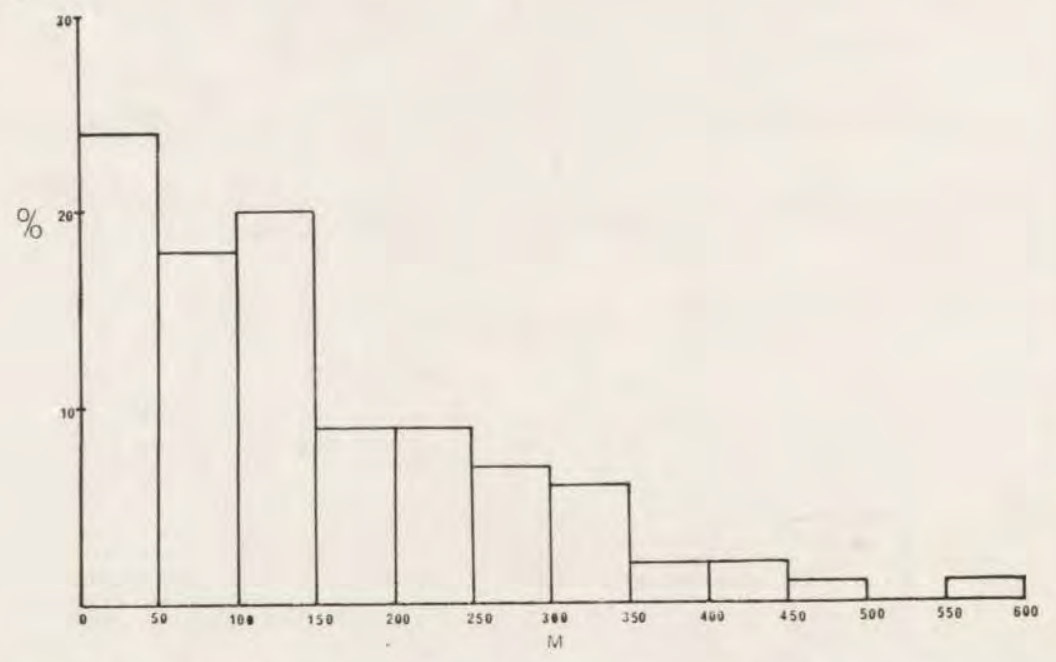

Fig. 2. The distance $(\mathrm{m})$ of sprainting sites (per cent of total) from the nearest used holt $(n=88)$.

Single spraints or small accumulations were found along the shore between holts, on isolateid bouldens on shingle beaches, inside many boathouses and around ruined cottages. Otters also marked the entrances of streams into the loch, irrespective of the size of stream and they marked their paths along the tops of cliffs (up to $100 \mathrm{~m}$ above M.H.W.S.). In two places, on an otter's cliff path, grass and bracken had been scraped into a heap with spraints deposited on top. 
The majority of sites with single or only a few spraints were in exposed positions. Forty eight $(32 \%)$ sprainting sites were not associated with cliffs and of these 15 marked the entrances of streams into the loch and 15 were associated with man-made structures (jetties, boathouses and ruined cottages).

A total of 168 sprainting sites including 18 "lavatories " was found (Fig. 1). Most commonly "lavatories" were in sheltered sites in hollows among the rocks which at first sight appeared to be potential holts but which, on further examination, proved unsuitable in not offering safe refuge. All but one site was dry. It is possible that otters may have used these sites as temporary lying up places but no evidence for this was found. Damp but otherwise similar positions were not utilized.

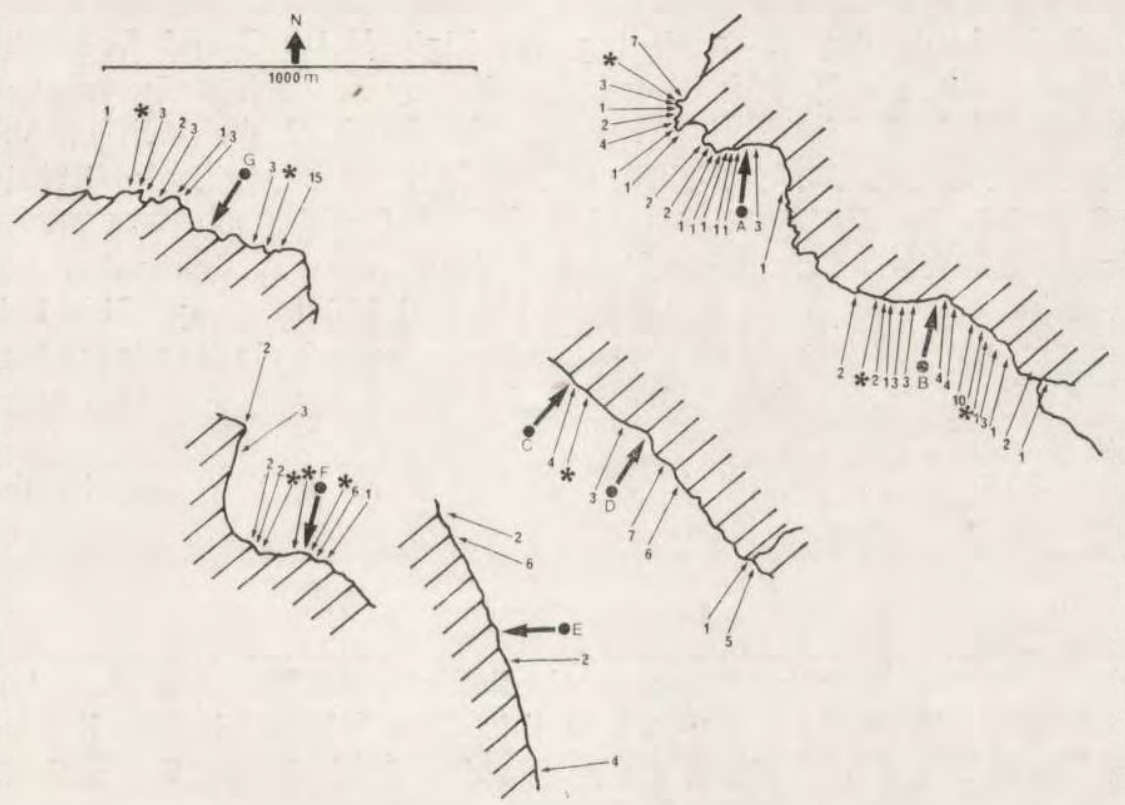

Fig. 3. The position and number of spraints and "lavatories" associated with seven selected holts. The location of holts $A-G$ is shown in Fig. 2. Shading designates the land. Symbols as in Fig. 1.

The distribution of "lavatories" in relation to holts was examined. Where holts occurred consecutively along the shore, interholt distances were calculated. Most of the upper basin and the long stretch of shingle and town in the lower basin were excluded since no holts were found in these areas and so they could not be treated as true interholt areas. Interholt distances thus amounted to $26.5 \%$ of the total shore 
examined. Three of the total of 18 "lavatories " were also excluded from the calculations as they lay at the seaward extremities of the survey area and so could have been associated with otters just outside the area examined. Eleven of the 15 »lavatories « $(73 \%)$ were between holts, a significantly greater number than expected (Fishers exact test, $P=0.0036$ ). Of the initial total of 18 »lavatories«, 7 were within $100 \mathrm{~m}$ of a holt.

The distribution of spraints in relation to holts is shown in Fig. 2. Elighty eight sprainting sites (including "lavatories«) were within $600 \mathrm{~m}$ of a holt. Marking was frequent up to $150 \mathrm{~m}$ from a holt after which the frequency of marking declined.

The pattern of marking around 7 representative holts is shown in Fig. 3. Holts $A$ and $B$ were on a rocky headland at the entrance to the loch and the frequency of sprainting was high. Holts $C$ and $D$, in the upper basin, were only $260 \mathrm{~m}$ apart and they were heavily marked in between. Holt $E$ (the holt nearest to the head of the loch on the southern shore) was only lightly marked; it was similarly lightly marked, and in use in September 1978. Holt $F$ (on the southern shore) contained an adult and cub(s). The loch is narrow at this point and holts on the northern shore were only 700 and $800 \mathrm{~m}$ away. This holt was heavily marked at its entrance and there were 3 "lavatories" close to it. Holt $G$, on the southern shore of the upper basin, was also quite heavily marked.

All sprainting sites found in September were still in use in the winter.

\subsection{Disturbance}

Loch Broom is subject to seasonal disturbance from tourism but parts of the loch are less exposed to this than others, due to limited access. There is no road along the seaward end of the southern shore and access is extremely idfficult. The terrain in this region comprises cliff and bog and it is unlikely that disturbance is high even in the summer. During the survey we found 6 unused holts in this stretch and it appeared that, despite the seclusion, the area was little used by otters, at least at the time of surveying.

The town of Ullapool with its harbour and fish market is an obvious source of disturbance and this was enhanced in September (and for several months ipreviously) both by tourism and by the influx of fishing vessels. We sighted otters, however, lin the loch during the day in September and fresh spraints were found around the town. During the winter survey several sprainting sites were located on the beach within the town boundaries and the fish market jetty was marked by 
otters. Local people informed us that otters were flushed regularly from a moored fishing vessel and they claimed that otters scavenged in the fish market. Otters also marked the entrances and inside boat houses although several of these were regularly used by man.

The nearest holt to the town of Ullapool was at a distance of $800 \mathrm{~m}$.

\section{DISCUSSION}

We found that, while the average straight line interholt distance on Loch Broom $(940 \mathrm{~m})$ was similar to that found by $\mathrm{Kruk}$ \& $\mathrm{He}$ w s on (1978) $(1100 \mathrm{~m})$, the holts on Loch Broom were not so evenly spaced but tended in places to be clumped. The distribution of holts appeared to be governeid largely by the topography of the area, being associated with rocky outcrops.

Kruuk \& Hew s on (1978) found that coastal otters marked the entrances to their holts while Erlinge (1968) found that riverine otters marked the boundaries of territories. $\mathrm{Kruuk} \& \mathrm{Hews}$ on (1978) suggested that these differences in marking patterns reflect the access routes into the territory by intruding otters. We found that coastal otters did mark the entrances to holts and that $62 \%$ of sprainting sites were withlin $150 \mathrm{~m}$ of a holt, a result comparable with the $60 \%$ found by Kruuk and Hewson. However, Kruuk \& Hew s on (1978) recorded $44 \%$ of all sprainting sites within $50 \mathrm{~m}$ of a holt and marking thereafter declined sharply with increasing distance from the holt. We found regular markling up to $150 \mathrm{~m}$ from a holt (see Fig. 2) followed by a decline. The distribution of spraints with distance in the two surveys are significantly different $\left(\chi^{2}=29.2, P<0.01\right)$.

Kruuk \& Hews on (1978) noted numbers of sprainting sites but not the abundance of spraints at each site and they make no mention of large accumulations of spraints away from holt sites. We found 18 "lavatories" and of these 11 were more than $100 \mathrm{~m}$ from a holt. Otters are known to spend much time travelling overland (E r linge, 1968; $\mathrm{V}$ e e n, 1975) and we found extensive otter trails in the snow. Even in a coastal situation the marking of overland approaches to holts may be as important as marking the holt itself to deter a trespassing animal.

It appeared that the areas around holts nearest to the sea were more heavily marked than holt sites further up the loch (c.f. Fig. 3, $A$ and $B$ with $C, D$ and $E$ ). It is likely that otters living on the seaboard would be more exposed to intrusion by unfamiliar otters from other areas. Holt $F$ was also heavily marked. This holt was situated at the narrowest part of the loch and holts on the opposite side ( $C$ and $D)$ were only 700 and $800 \mathrm{~m}$ away (Fig. 1). Close proximity of holts may affect marking patterns and a "lavatory" occurred between $C$ and $D$, 
but the environs of these holts were not as heavily marked as the area around $F$. Evidence of $c u b(s)$ was found at holt $F$. The area around holt $G$ was also heavily marked and again thlis holt was situated at a narrow part of the loch but no evidence of cubs was found. Further work on the distribution of spraints around holts with known occupants is required.

W a ts o n (1978) found that otters spent most of their time foraging where the seabed was covered with kelp. Hunting may not, however, be particularly elasy in such a habitat because the duration of dives was found by Kruuk \& Hewison (1978) to be long and otters would travel up to $700 \mathrm{~m}$ from their holts to forage. Nevertheless, although searching time is long because food is caught amongst rock and weed, the supply is dependable and resources would be renewed with each tidal cycle from prey organisms produced outside the normal foraging range of otters (no further than $100 \mathrm{~m}$ off shore according to $\mathrm{Kru} \mathrm{uk} \& \mathrm{H}$ e w s o n, 1978). If the otters range is related to resources, then the range of a coastal otter need not be large. Kru u k \& Hew Son (1978) suggest that foraging areas are used communally. In contrast, territories of riverine otters need to be large to secure adequate resources of food. In rivers most food items, apart from migratory fishes, are produced within the range and there is not a reservoir of resources in unexploitable habitat to replenish stocks.

We might expect territories in lakes to be intermediate in size because otters can forage outwards from the shore and stocks may be replenished from deep and distant areas outwith the otters foraging capabilities. Erling e's data (1968) suggest that this is so.

Disturbance by man variets seasonally on Lach Broom and some areas are more secluded than others. The distribution of signs of otter activity was more closely related to the topography of the area than to levels of disturbance in different parts of the loch. Spraints were deposited in boathouses, on the beach within the town boundaries and on the fish market jetty. Wats on (1978) found otters breeding in a jetty in Shetland despite the daily arrival of a ferry. It is suggested that otters will tolerate a certain level of human disturbance provided that sufficient safe refuges are available.

\section{REFERENCES}

1. Erlinge S., 1968: Territoriality of the otter Lutra lutra L. Oikos, 19: 81-98.

2. Kruuk H. \& Hewson R., 1978: Spacing and foraging of otters (Lutra lutra) in a marine habitat. J. Zool. (Lond.), 185: 205-212.

3. Macdonald S. M., Mas on C. F. \& Coghill I. S., 1978: The otter and ils conservation in the River Teme catchment. J. Appl. Ecol., 15: 373-384. 
4. Milne P. H., 1972: Hydrography of Scottish west coast sea lochs. Marine Research - 1972 No. 3. Edinburgh H.M.S.O.: 50 pp.

5. Nature Conservancy Council, 1977: Otters 1977. First report of the Joint N.C.C./S.P.N.C. Otter Group, London: $26 \mathrm{pp}$.

6. Ve e n J., 1975: Het voorkomen en enige gedragsverschijnselen van de visotter, Lutra lutra (Linnaeus, 1758), in Noord - Holland. Lutra, 17: 21-37.

7. Wats on H., 1978: Coastal otters in Shetland. Unpublished Report: 92 pp. Accepted, October 31, 1979.

\section{S. M. MACDONALD i C. F. MASON}

\section{OBSERWACJE NAD SPOSOBEM ZNAKOWANIA TERENU U PRZYBRZEZNEJ POPULACJI WYDRY}

\section{Streszczenie}

Badano znakowanie terenu przez populację wydry Lutra lutra (Linnaeus, 1758), zamieszkującą wąską zatokę morską w północno-zachodniej Szkocji. Obserwacje prowadzono wzdłuż brzegu na długości $32 \mathrm{~km}$ (Ryc. 1). Znaleziono 12 wykorzystywanych miejse bytowania wydr. Byly one usytuowane na klifowych skałach a średnia odległość między nimi wynosila $1100 \mathrm{~m}$ (zakres od 450 do $2000 \mathrm{~m}$ ). Wejścia do miejsc bytowania były silnie znakowane kałem. Duże nagromadzenia kalu (,klozety") występują między tymi miejscami i mogą służyć jako sygnały dla wydr plynących wzdłuż brzegu. $62 \%$ ze 168 „klozetów” znajdowało się w odległości $150 \mathrm{~m}$ od miejsc bytowania (Ryc. 2 i 3). Znakowanie terenu przez wydry zależy od topografii terenu i poziomu zakłóceń spowodowanych przez ludzi w różnych częściach zatoki. 